\title{
Properties of a marine ice layer under the Amery Ice Shelf, East Antarctica
}

\author{
Mike CRAVEN, ${ }^{1}$ Ian ALLISON, ${ }^{1}$ Helen Amanda FRICKER, ${ }^{2}$ Roland WARNER ${ }^{1}$ \\ ${ }^{1}$ Australian Antarctic Division and Antarctic Climate and Ecosystems CRC, Hobart, Tasmania 7001, Australia \\ E-mail:m.craven@utas.edu.au \\ ${ }^{2}$ Institute of Geophysics and Planetary Physics, Scripps Institution of Oceanography, University of California-San Diego, \\ La Jolla, California 92093-0225, USA
}

\begin{abstract}
The Amery Ice Shelf, East Antarctica, undergoes high basal melt rates near the southern limit of its grounding line where $80 \%$ of the ice melts within $240 \mathrm{~km}$ of becoming afloat. A considerable portion of this later refreezes downstream as marine ice. This produces a marine ice layer up to $200 \mathrm{~m}$ thick in the northwest sector of the ice shelf concentrated in a pair of longitudinal bands that extend some $200 \mathrm{~km}$ all the way to the calving front. We drilled through the eastern marine ice band at two locations $70 \mathrm{~km}$ apart on the same flowline. We determine an average accretion rate of marine ice of $1.1 \pm 0.2 \mathrm{~m} \mathrm{a}^{-1}$, at a reference density of $920 \mathrm{~kg} \mathrm{~m}^{-3}$ between borehole sites, and infer a similar average rate of $1.3 \pm 0.2 \mathrm{ma}^{-1}$ upstream. The deeper marine ice was permeable enough that a hydraulic connection was made whilst the drill was still $70-100 \mathrm{~m}$ above the ice-shelf base. Below this marine close-off depth, borehole video imagery showed permeable ice with water-filled cavities and individual ice platelets fused together, while the upper marine ice was impermeable with small brine-cell inclusions. We infer that the uppermost portion of the permeable ice becomes impermeable with the passage of time and as more marine ice is accreted on the base of the shelf. We estimate an average closure rate of $0.3 \mathrm{~m} \mathrm{a}^{-1}$ between the borehole sites; upstream the average closure rate is faster at $0.9 \mathrm{~m} \mathrm{a}^{-1}$. We estimate an average porosity of the total marine ice layer of $14-20 \%$, such that the deeper ice must have even higher values. High permeability implies that sea water can move relatively freely through the material, and we propose that where such marine ice exists this renders deep parts of the ice shelf particularly vulnerable to changes in ocean properties.
\end{abstract}

\section{INTRODUCTION}

Substantial layers of marine ice have been reported for several of the major Antarctic ice shelves including portions of the Filchner-Ronne Ice Shelf (Thyssen, 1988; Oerter and others, 1992; Lambrecht and others, 2007) and the Amery Ice Shelf (AIS) (Morgan, 1972; Fricker and others, 2001). In contrast, there is very little marine ice under the Ross Ice Shelf (Neal, 1979) or any of the Antarctic Peninsula ice shelves. Marine ice is produced by the formation of platelet (frazil) ice crystals in the water column, via the ice-pump mechanism (Lewis and Perkin, 1986; Jacobs and others, 1992). The temperature at which ice coexists with sea water (colloquially the sea-water freezing point) decreases with pressure (depth), and consequently the rate of basal melt near the grounding line depends on the ice draft, as well as the sub-ice circulation and the temperature of the inflowing ocean. The formation of frazil ice crystals occurs when the more buoyant cooled and freshened water produced by melting basal ice becomes supercooled as it rises to lower pressures. These frazil crystals attach to the base of the shelf and coalesce into a consolidated unit (Engelhardt and Determann, 1987; Oerter and others, 1992; Bombosch and Jenkins, 1995; Grosfeld and others, 1997). The deposition of frazil as marine ice also depends on the size of the growing platelets, the subice currents and the shape of the ice-shelf base (Bombosch and Jenkins, 1995). The buoyancy forcing from melting also contributes to the strength of the circulation.

From hydrostatic considerations of a digital elevation model (DEM) (Fricker and others, 2000) the AIS (Fig. 1) has a draft of $\sim 2500 \mathrm{~m}$ in its deepest part near the southern grounding zone around $73.2^{\circ} \mathrm{S}$ (Fig. 2). The sea-water freezing point at the deep grounding line is $-3.8^{\circ} \mathrm{C}$ (Millero, 1978), nearly $2^{\circ} \mathrm{C}$ below the surface freezing point. The southern AIS therefore experiences intense basal melting (Rignot and Jacobs, 2002), enhancing ice-shelf basal gradients and generating a strong ice-pump mechanism in the sub-ice cavity. The mass influx into the shelf across the grounding line (at about $73.2^{\circ} \mathrm{S}$ ) from Lambert, Mellor and Fisher Glaciers is $\sim 54 \mathrm{Gt} \mathrm{a}^{-1}$ (Wen and others, 2008), but the mass flux almost halfway down the shelf through the G3 section of Budd and others (1982), transversely across the AIS at $71.0^{\circ} \mathrm{S}$, is only $\sim 8.4 \mathrm{Gta}^{-1}$ (Wen and others (2007) report similar losses). More than $80 \%$ of the continental ice from these streams is lost through basal melting beneath the southernmost $240 \mathrm{~km}$ of the AIS, which contributes to the formation of cold, dense Ice Shelf Water (ISW).

Ice radio-echo sounding (RES) measurements can be used to detect the marine/meteoric ice interface. Total ice thicknesses can be derived via buoyancy considerations from an ice-shelf DEM generated from European Remotesensing Satellite (ERS-1) radar altimetry elevations (AIS-DEM; Fricker and others, 2000). The difference between the DEMderived and RES thicknesses can then be used to reveal the spatial distribution of the AIS marine ice layer (Fricker and others, 2001). For the AIS the marine ice is largely concentrated in two extensive bands, which are over $150 \mathrm{~m}$ thick in places, aligned along-flow in the northwest quadrant (Fig. 1). The marine ice accretion process, following frazil production from the ISW generated by basal melt, means that a considerable fraction of the mass lost to the south is redeposited in the northwest sector of the AIS. 


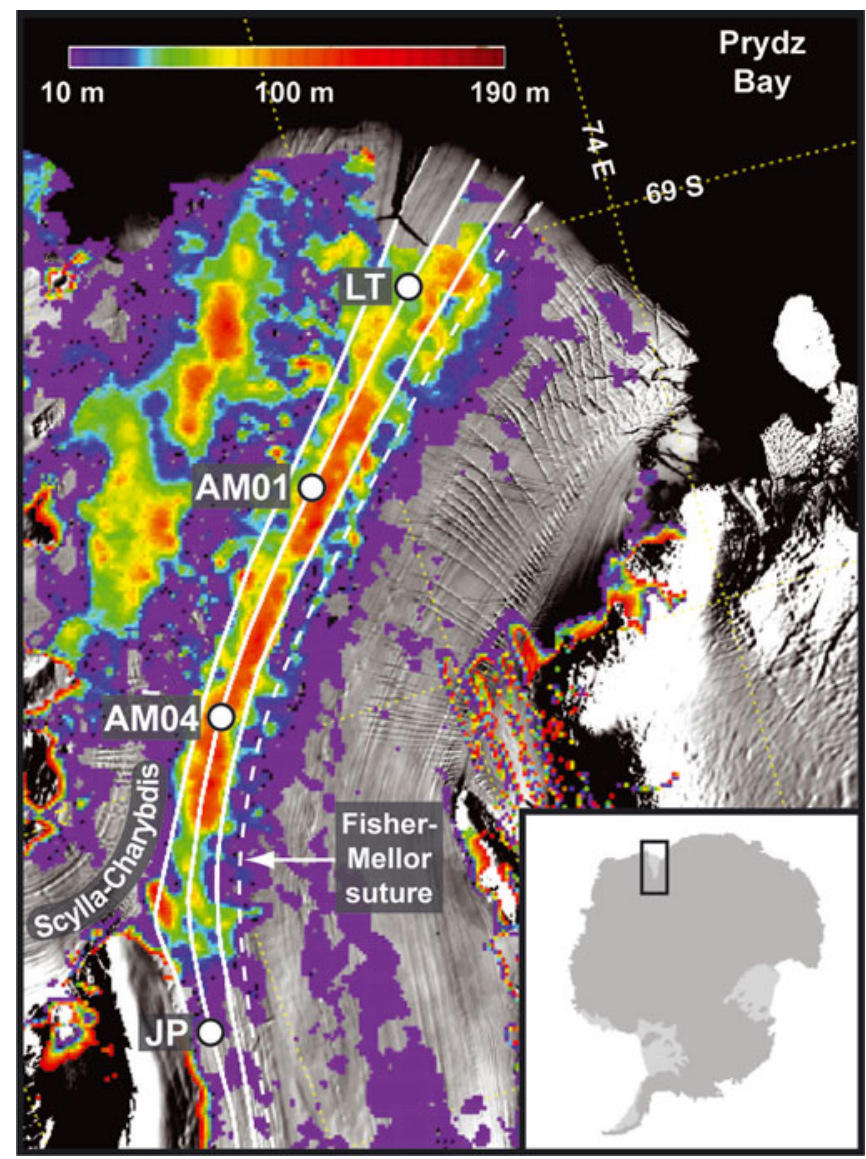

Fig. 1. The Amery Ice Shelf from the MODIS (moderate-resolution imaging spectroradiometer) Mosaic of Antarctica (MOA; Scambos and others, 2007), showing sites discussed in the text. From upstream: Jetty Peninsula point (JP), where marine ice band accretion begins; AM04 and AM01 boreholes; and the 'Loose Tooth' point (LT). Also shown are flowbands from tributary glaciers centred on the borehole flowline; the location of the Fisher-Mellor ice-shelf profile flowline shown in Figure 2 (dotted); and colour shading (scale top left) of the estimated marine ice thickness (Fricker and others, 2001). For scale the boreholes AM01-AM04 are approximately $68 \mathrm{~km}$ apart. The Budd Ice Rumples are south of the area shown, $140 \mathrm{~km}$ upstream along the flowline from JP. Inset shows location of the Amery Ice Shelf.

Examination of elevation profiles transverse to the ice flow shows that marine ice generally occurs beneath regions of lower surface elevation, although clearly iceshelf draft is only one factor in marine ice accretion. The thickest marine ice in the eastern band develops beneath a flowband of relatively lower elevation, although towards the ice front marine ice also occurs beneath a small surface topographic high (relative to a transverse cross-section) along the Fisher/Mellor 'suture' flowline (Fig. 1). Marine ice accretion tends to level the underside of the ice shelf although, as discussed later, marine ice is considerably denser than meteoric ice. The AIS marine ice layer persists all the way to the ice front (Fricker and others, 2001). In contrast, the central Ronne Ice Shelf marine ice layer was previously melted completely by a warm sub-shelf current before it reached the front (Thyssen and others, 1993). Following major iceberg calving events that occurred between 1986 and 2000, the length of the Ronne Ice Shelf has been reduced enough that its marine ice layer now also extends to the front (Lambrecht and others, 2007).

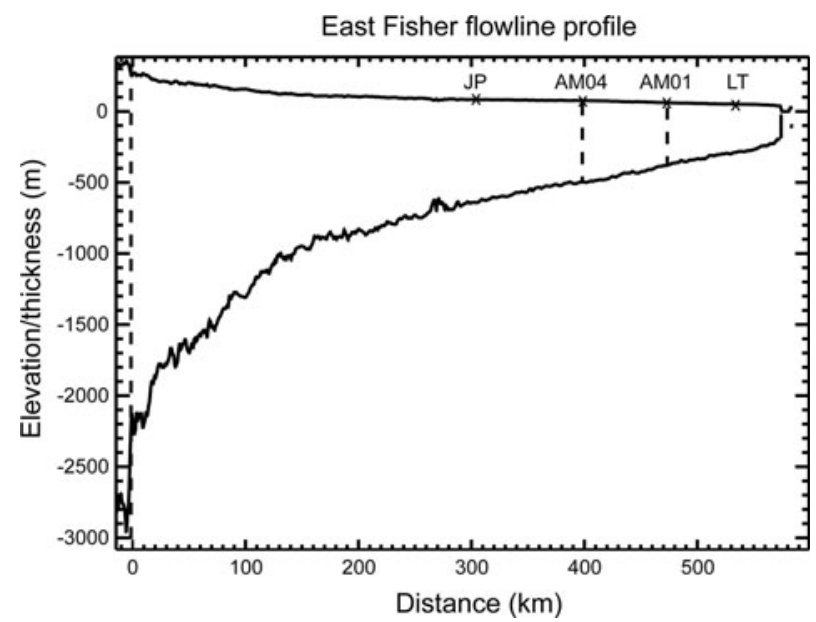

Fig. 2. Surface elevation (AIS-DEM) and thickness profile (AISSDEM derived) along a central flowline (Fisher-Mellor suture) of the Amery Ice Shelf from the $>2500 \mathrm{~m}$ thick grounding zone near $73.2^{\circ} \mathrm{S}$ to the calving front at $68.5^{\circ} \mathrm{S}$. The approximate positions of points discussed in the text are shown relative to this flowline, although these points are adjacent to, and not on, the flowline.

Marine ice is distinctly different from meteoric ice. It contains brine cells incorporated within the ice matrix (Eicken and others, 1994; Moore and others, 1994). The presence of brine inclusions affects the recrystallization processes as the pores in the marine ice close. Understanding the mechanical structure of marine ice is important for its realistic treatment in ice-shelf models.

To investigate the nature of AIS marine ice, we drilled through the eastern band at two sites $68 \mathrm{~km}$ apart along the same flowline over three field seasons (2000/01, 2003/04 and 2005/06) using a hot-water drill (HWD; Craven and others, 2004, 2005). Preliminary results suggested that the lowest $100 \mathrm{~m}$ layer at one of the sites was highly permeable, with rectangular banded textural facies (Craven and others, $2004,2005)$. In this paper, we show that results from the second borehole, drilled in 2005/06, confirm this observation. We present physical properties of the marine ice layer inferred from measurements made through the two boreholes, including estimates of accretion rate and pore closure rate along the flowband. We also discuss the potential role of the marine ice in the dynamics of the AIS and its future evolution in response to climate change.

\section{FIELD MEASUREMENTS}

A modular HWD system was used to collect short core sections and melt boreholes through the AIS into the subice-shelf cavity. Measurements and samples were taken from the ice and underlying ocean through the boreholes. The two borehole sites, AM01 and AM04, were located approximately on the same flowline, 100 and $170 \mathrm{~km}$ respectively from the calving front. These sites were selected to target the eastern marine ice band, which extends northeast from the vicinity of Jetty Peninsula approximately $250 \mathrm{~km}$ to the centre of the ice front (Fig. 1). A hot-water coring head (Engelhardt and others, 2000) was used to collect short icecore samples of $<1 \mathrm{~m}$ length at selected depths in the ice column during drilling. A video camera system was deployed down the borehole to record images of the borehole walls for investigation of ice characteristics 


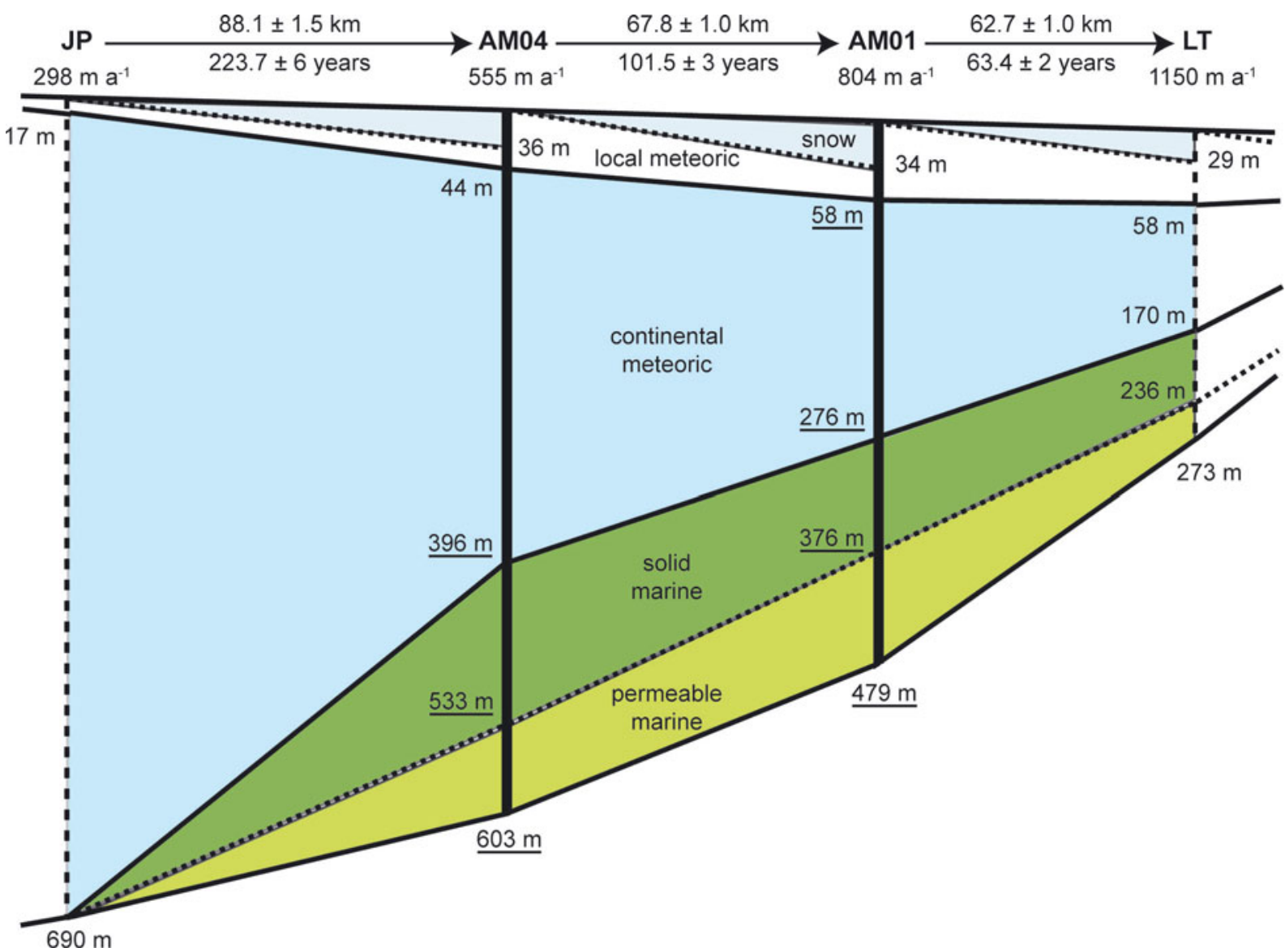

Fig. 3. Thicknesses of ice layers along the AM04-AM01 flowband. From the top: new local accumulation between sites (grey); cumulative local accumulation (white); continental meteoric ice (blue); impermeable marine ice (dark green); and permeable marine ice (light green). Underlined quantities are measured directly from the boreholes; non-underlined quantities are derived from these and other measured iceshelf characteristics (surface speeds and flowband widths).

(Craven and others, 2005). At both sites, we also made global positioning system (GPS) observations and snow accumulation measurements.

\subsection{AM01 boreholes}

AM01 $\left(69.442^{\circ} \mathrm{S}, 71.417^{\circ} \mathrm{E} ; 100 \mathrm{~km}\right.$ from the ice-shelf calving front) was at the same geographic location as the historic site G1, where an ice core was mechanically drilled to $315 \mathrm{~m}$ depth in 1968 and from which the presence of a marine ice layer in the AIS was first detected (Morgan, 1972). Stable-isotope analysis of the 1968 core showed that the ice shelf at G1 consisted of three layers: the upper $70 \mathrm{~m}$ formed from local snow accumulation $(58.2 \mathrm{~m}$; see section 4.2); the middle 70-270 m continental meteoric ice that had flowed from the interior of the Lambert Glacier basin; and a basal layer (below 270 m) composed of marine ice. Higherresolution results from recent drilling (discussed below) put the meteoric/marine ice transition at this site at $276 \mathrm{~m}$ depth. The thickness of the marine ice layer was not measured directly in 1968, but was estimated to be in the range 158$196 \mathrm{~m}$ based on two different values for the total shelf thickness: an ice radar thickness of $428 \mathrm{~m}$ measured during a January 1970 surface survey about $10 \mathrm{~km}$ east of the drill site; and a local thickness of $466 \mathrm{~m}$ estimated from buoyancy calculations using the measured G1 density profile (Morgan, 1972). For the record, we note that inclement weather during the 1968 deployment forced the G1 drill camp to be placed $10 \mathrm{~km}$ west of an earlier G1 grid site, which had marked the crossroads of longitudinal and transverse survey lines on the AIS (Budd and others, 1982; Corry, 1987). There has been some confusion, in the subsequent literature, regarding this relocation.

Recent mapping of the spatial distribution of the marine ice from hydrostatic calculations using satellite radar altimeter elevations and airborne radar soundings of the meteoric/marine ice interface indicates a marine ice thickness (using a firn density model and assumed density for marine ice of $917 \mathrm{~kg} \mathrm{~m}^{-3}$ ) at AM01 of $141 \pm 30 \mathrm{~m}$ (Fricker and others, 2001).

The AM01 borehole was drilled in the summer of 2001/ 02. A hydraulic connection with the sub-shelf cavity, similar to that reported in drilling the Ronne Ice Shelf (Makinson, 1993), was registered whilst the drill head was at only $376 \mathrm{~m}$ depth, and a total ice-shelf thickness of $479 \mathrm{~m}$ was measured (Fig. 3). Four ice-core samples, each $<1 \mathrm{~m}$ long, were collected several days later from a second hole drilled adjacent to the main borehole. These samples were of continental ice at $240 \mathrm{~m}$ depth, and marine ice at 290, 360 and $390 \mathrm{~m}$ depth, the last sample being from below the hydraulic connection depth (Craven and others, 2004).

AM01 was revisited in the summer of 2003/04, by which time it had moved $1.6 \mathrm{~km}$ northeast with ice-shelf flow. A new borehole (AM01b) was drilled at this geographical location, primarily to deploy a digital video camera system with real-time viewing capabilities (Carsey and others, 2002) to examine both the ice in the borehole walls and 


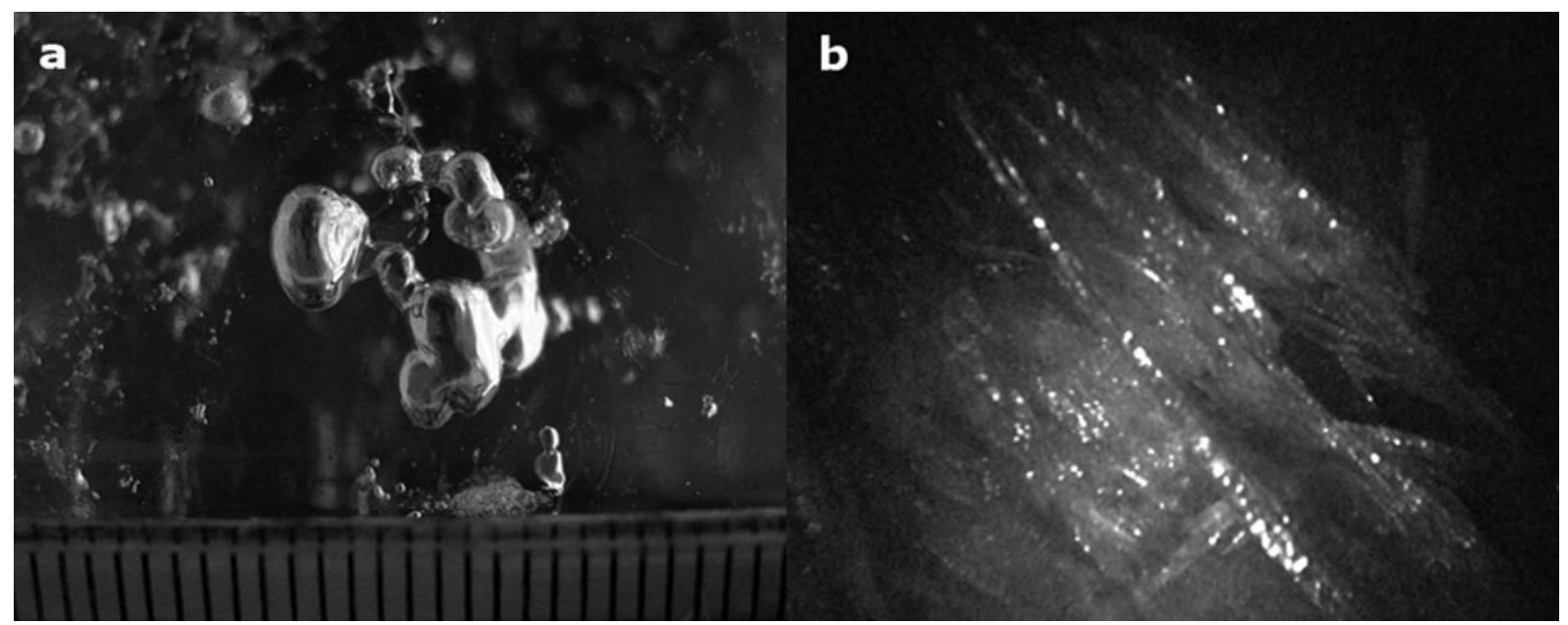

Fig. 4. (a) Marine ice sample from $450 \mathrm{~m}$ depth at AM04 with millimetre size cells (scale with mm gradations across bottom), possibly containing trapped brine. (b) Video image from near the base of the shelf showing thin platelets stacked together, seen largely edge-on. Whilst the exact scale is uncertain, the platelets are probably $10 \mathrm{~mm}$ or more in diameter.

the ocean bed beneath the site (Craven and others, 2005). The hydraulic connection depth (around $376 \mathrm{~m}$ ) was not directly measured in AM01b because of instrument failure. Instead, we used the video system to estimate total shelf thickness $(479 \mathrm{~m})$, and locate the meteoric/marine ice interface depth at $276 \mathrm{~m}$. This was subsequently confirmed from an independent $296 \mathrm{~m}$ deep ice core collected from within a few hundred metres of the AM01/AM01b site by a 2002/03 Chinese National Antarctic Research Expedition (CHINARE; personal communication from Li Yuansheng, 2006). The total thickness of the marine ice layer at this site was $203 \mathrm{~m}$, with the lower $103 \mathrm{~m}$ of this (below the hydraulic connection depth at $376 \mathrm{~m}$ ) being permeable, though consolidated. We retrieved two new ice-core samples from AM01b at $250 \mathrm{~m}$ depth (meteoric ice) and just below the transition at $276 \mathrm{~m}$ (marine ice).

\subsection{AM04 borehole}

A borehole at a second site on the same flowline as AM01, but $\sim 70 \mathrm{~km}$ upstream, (AM04: 69.900 ${ }^{\circ} \mathrm{S}, 70.290^{\circ} \mathrm{E} ; 170 \mathrm{~km}$ from the ice front) was drilled in the summer of 2005/06. At this site, interpolation from the distribution of Fricker and others (2001) gave an estimated marine ice thickness of $131 \pm 30 \mathrm{~m}$. The total shelf thickness measured in the borehole was $603 \mathrm{~m}$. We attained hydraulic connection in the depth range $530-535 \mathrm{~m}$, with relaxation to an equilibrium water level in the subsurface well undergoing a more gradual response than that experienced at AM01. A video system was deployed down the borehole, although it did not have the full fibre-optic capability of that used at AM01b and there was no real-time viewing available during operation. Interface and basal depth measurements were obtained from video observations acquired by lowering the system to specific depths on the instrument winch cable.

At $\mathrm{AM04}$, ice-core samples were retrieved from depths of $350 \mathrm{~m}$ (meteoric ice) and from 400, 450 and $500 \mathrm{~m}$ (all marine ice). On-site inspection of the $400 \mathrm{~m}$ depth core found bands of debris that were largely confined to strings or near-horizontal planes, evidence that they had come from somewhere near the very top of the marine ice layer (Eicken and others, 1994; Moore and others, 1994; Craven and others, 2005). Subsequently this region of the borehole was examined with the video camera, and the meteoric/marine ice interface was detected at $396 \mathrm{~m}$ depth, implying that the marine ice layer was $207 \mathrm{~m}$ thick at this site, the lowest $68-73 \mathrm{~m}$ of which was permeable.

\section{CHARACTERISTICS OF MARINE ICE}

Examination of vertical thin sections of the marine ice-core samples showed that they all had a platelet crystal structure, with no evidence of congelation marine ice growth (personal communication from A. Treverrow, 2007). Core samples taken from the top of the marine ice layer at both AM01 and AM04 contained debris strings or bands that have been shown to contain both biogenic and mineral particles (Roberts and others, 2007). They also contained millimetresized pores (Fig. 4a) and/or sinuous veins, which appeared to become more prevalent with depth. These have previously been interpreted as brine cells, which originate from pockets of sea water trapped within the marine ice as it formed (Engelhardt and Determann, 1987; Eicken and others, 1994; Tison and others, 2001). Chemical analysis (ion chromatography) of the marine ice in the AM01 core samples revealed that total salinity increases by an order of magnitude from around $0.03 \%$ near the meteoric/marine ice interface, to $0.56 \%$ at $120 \mathrm{~m}$ below the boundary (Craven and others, 2005), confirming an increased prevalence of brine inclusions with depth. This deepest sample, from the permeable ice zone, may have suffered drainage of larger pores during coring, and may not reflect the true bulk salinity of the marine ice-sea-water matrix in the region. The low salinity value near the meteoric/marine interface is similar to values from the upper portions of the Ronne Ice Shelf marine ice at the B13 borehole (Eicken and others 1994).

Our borehole video showed that deep within the marine ice layer (typically the bottom $40-50 \mathrm{~m}$ of the ice shelf), the ice texture had a layered flaky appearance (Fig. 4b) with ice platelets fused together forming a matrix filled with interstitial sea water, which was previously referred to as 'honeycomb' ice (Craven and others, 2005). Caliper measurements through the meteoric and upper marine ice sections at AM01 showed a smooth, nearly constant-diameter borehole, but at depth in the permeable marine ice the borehole diameter was 
narrower and more variable. This resulted from loss of heat from the drilling head into sea-water-filled cavities within the permeable marine ice. The irregular nature of the borehole walls deep within the shelf was also evident at AM04 in downward-looking video imagery. Despite its nature, this permeable ice layer had structural integrity all the way to the base. The weight of a $50 \mathrm{~kg}$ inclinometer was still supported by the bottom of the incomplete borehole at $600 \mathrm{~m}$ depth at AM04, only $3 \mathrm{~m}$ above the level where the base was eventually penetrated. This is unlike unconsolidated slush reported at the base of the Ronne Ice Shelf, which partially filled the lower tens of metres of the borehole after drilling (Engelhardt and Determann, 1987). We experienced no such filling toward the base, even following several reaming runs to warm the borehole to prevent it freezing during sampling, with the potential to dislodge crystals only loosely attached to the walls.

It is highly likely that the Ronne borehole was a site of active refreezing, with a frazil production event occurring during the drilling period. Modelling has shown that deposition of the majority of suspended frazil ice occurs in spatially discrete bursts (Bombosch and Jenkins, 1995). Oceanographic data from the cavity below AM01 show a strong seasonal cycle in the water temperature, salinity and freezing processes (Leffanue and Craven, 2004), so we expect deposition to also show temporal variability. Similarly, while it is believed that AM04 is an active refreezing site, oceanographic data also show strong seasonality there. No frazil production was detected during AM04 borehole operations either by interference to deployment of oceanographic instruments, as reported beneath the Ronne Ice Shelf during drilling (Engelhardt and Determann, 1987), or directly by video observations at that time.

Marine ice well above the hydraulic connection depth is impermeable but has brine pores incorporated within it (analogous to bubbles in meteoric ice). Marine ice below the hydraulic connection clearly has interconnected cells and channels (analogous to firn); we refer to this as permeable marine ice. The hydraulic connection depth is an approximation of the effective pore close-off depth. Both marine ice types are consolidated and have structural integrity.

\section{MASS BALANCE FOR ICE-SHELF LAYERS ALONG FLOWBANDS}

\subsection{Mass-balance components}

The AIS is an embayed ice shelf, confined within the topography of the Prydz Bay inlet. As ice flows north, the embayment widens and the ice flow diverges and accelerates; this transverse and longitudinal spreading is necessarily accompanied by vertical strain thinning.

If the ice shelf is in steady state, then the continuity equation (Budd and others, 1982) along a flowband is

$$
\dot{a}_{\mathrm{s}}+\dot{a}_{\mathrm{b}}-U \frac{\partial Z}{\partial x}-Z \frac{\partial U}{\partial x}-\frac{U Z}{Y} \frac{\partial Y}{\partial x}=0,
$$

where $\dot{a}$ is the rate at which mass is added at the surface (subscript s; snow accumulation/ablation) and at the base (subscript b; marine ice accretion/basal melt) of the ice shelf, $x$ is the distance along the flowband, $U$ is the horizontal flow velocity (constant across the band for narrow flowbands), $Z$ is the ice thickness (constant across the band for narrow flowbands) and $Y$ is the flowband width. This continuity equation not only holds for the ice-shelf column as a whole, but also for the individual layers within the shelf, except that internal layers have no sources of additional mass.

Since the ice is floating, the strain rate is constant with depth (e.g. Sanderson and Doake, 1979) and different ice layers (locally accumulated meteoric ice, inland meteoric ice and basally accreted marine ice) each undergo the same rate of thinning.

The incompressible character of ice means that the vertical strain rate $\left(\dot{\varepsilon}_{z}\right)$ for the flowband is connected with the variation in speed along the flow, and the transverse spreading of the flow, via flow strain rates $\dot{\varepsilon}_{x}$ (longitudinal) and $\dot{\varepsilon}_{y}$ (transverse) as

$$
\dot{\varepsilon}_{z}=-\left(\dot{\varepsilon}_{x}+\dot{\varepsilon}_{y}\right)=-\frac{\partial U}{\partial x}-\frac{U}{Y} \frac{\partial Y}{\partial x} .
$$

For an internal layer with no addition or loss of mass, and with a constant strain rate over the interval, the relative thinning of an arbitrary flowband between an upstream point (subscript 1) and a downstream point (subscript 2) is

$$
\dot{\varepsilon}_{z} \Delta t=\ln \left(\frac{Z_{2}}{Z_{1}}\right)=\ln \left(\frac{U_{1} Y_{1}}{U_{2} Y_{2}}\right)
$$

where $\Delta t$ is the increment of time taken for the ice to flow between the two points. The compounding effect is strictly correct if $\dot{\varepsilon}_{z}$ is constant with time, and it is a good approximation if the variation of $\dot{\varepsilon}_{z}$ is small.

For the upper and lower shelf layers we need to also consider surface accumulation/ablation, and basal accretion/melt. The accumulated snow on the top, and accreted marine ice on the bottom also undergo strain thinning, but since they are added incrementally along the flowband they only undergo a proportion of the total thinning between upstream and downstream sites. Although both snow accumulation and marine ice accretion have a seasonal variability, we have no information on what these are. We adopt the simplifying assumption that the rates of addition have constant annual values between the sites. The thickness of such a layer of ice downstream compared to its thickness upstream is then

$$
Z_{2}=Z_{1} \mathrm{e}^{\dot{\varepsilon}_{z} t}+\frac{\dot{a}}{\dot{\varepsilon}_{z}}\left(\mathrm{e}^{\dot{\varepsilon}_{z} t}-1\right) .
$$

The first term on the right-hand side is the strain thinning of the ice already present at the upstream site (Equation (3)), and the second term is the strain thinning of the new ice incrementally added along the flowband.

\subsection{Application to the AM01-AM04 flowband}

Using the borehole data and ancillary field measurements, we estimated ice-shelf speeds, ice layer thicknesses and accumulation at sites along the flowband through AM04 and AM01 (Table 1). An error analysis has been made for all quantities calculated and these are included in the tables.

We calculated the average strain rate between AM04 and AM01 from Equation (2), using the data in Tables 1 and 2 to estimate average values and gradients in velocity and flowband width, yielding

$$
\dot{\varepsilon}_{z}=-0.0059 \mathrm{a}^{-1} \text {, so that } \mathrm{e}^{\dot{\varepsilon}_{z} t}=0.55,
$$

where the time $(t)$ for ice to travel between the two sites is 101.5 years (Table 1). The result using Equation (3) is the same, which is not surprising as the two are implicitly linked via the travel time and distance between the sites. This second estimate (derived from speed and flowband width data) validates our assumption that the rate of change of 
Table 1. Glaciological parameters measured at AM04 and AM01 borehole sites and estimated at JP and LT (Fig. 1). Meteoric ice thicknesses at JP and LT are from radio-echo sounding in the vicinity of the sites, and therefore have greater error limits than borehole measurements at AM01 and AM04. Surface flow speeds are from local GPS measurements at AM01 and AM04, and from satellite remote sennsing (Young and Hyland, 2002) at JP and LT. Accumulation is given in $\mathrm{m} \mathrm{a}^{-1}$ (snow) at the mean density of the upper $20 \mathrm{~m}$ of firn measured at AM01 $\left(550 \mathrm{~kg} \mathrm{~m}^{-3}\right.$ ). This provides a representative ice-shelf thickness change due to accumulation at each location. Flowband width was estimated from the MODIS Mosaic of Antarctica (MOA; Scambos and others, 2007; pixel size $0.125 \mathrm{~km}$ )

\begin{tabular}{|c|c|c|c|c|c|c|c|}
\hline \multirow[t]{2}{*}{ Site } & \multirow{2}{*}{$\begin{array}{c}\text { Meteoric ice } \\
\text { thickness } \\
\text { m }\end{array}$} & \multirow{2}{*}{$\begin{array}{c}\text { Marine ice } \\
\text { thickness } \\
\text { m }\end{array}$} & \multirow{2}{*}{$\begin{array}{c}\text { Surface elevation } \\
\text { (WGS84) } \\
\text { m }\end{array}$} & \multirow{2}{*}{$\begin{array}{c}\text { Snow } \\
\text { accumulation } \\
\mathrm{ma}^{-1} \text { (snow) }\end{array}$} & \multirow{2}{*}{$\begin{array}{l}\text { Surface speed } \\
\qquad \mathrm{m} \mathrm{a}^{-1}\end{array}$} & \multicolumn{2}{|c|}{ Flowband width } \\
\hline & & & & & & $\mathrm{km}$ & (relative) \\
\hline$J P$ & $690 \pm 20$ & 0 (assumed) & - & $0.11 \pm 0.02$ & $298 \pm 5$ & $9.6 \pm 0.5$ & $1.00 \pm 0.07$ \\
\hline AM04 & $396 \pm 2$ & $207 \pm 2$ & $71.7 \pm 1$ & $0.35 \pm 0.04$ & $555 \pm 5$ & $11.1 \pm 0.5$ & $1.16 \pm 0.08$ \\
\hline AM01 & $276 \pm 2$ & $203 \pm 2$ & $60.7 \pm 1$ & $0.54 \pm 0.06$ & $804 \pm 5$ & $13.9 \pm 0.5$ & $1.45 \pm 0.09$ \\
\hline LT & $170 \pm 12$ & - & - & $0.71 \pm 0.08$ & $1150 \pm 5$ & $19.2 \pm 0.5$ & $2.00 \pm 0.12$ \\
\hline
\end{tabular}

strain rate is small over the period. Budd and others (1982) estimated that the vertical strain rate over a similar interval of the central AIS flowband ranges from $-0.0042 \mathrm{a}^{-1}$ to $-0.0075 \mathrm{a}^{-1}$ (an average of $-0.0058 \mathrm{a}^{-1}$ ).

We can further check the applicability of using average strain rates and accumulation rates in Equation (4), over a period of more than 100 years, by comparing the thickness of meteoric ice measured at AM01 with that estimated from strain thinning of the original meteoric ice at $\mathrm{AMO} 4$ plus new snow accumulation. Between AM04 and AM01 the annual average accumulation $\left(\dot{a}_{\mathrm{s}}\right)$ is $0.44 \mathrm{ma}^{-1}$ of snow at an average density of $550 \mathrm{~kg} \mathrm{~m}^{-3}$ (the mean value measured for the upper $20 \mathrm{~m}$ of firn at AM01; Table 1). The $45 \mathrm{~m}$ of new snow thickness accumulated between these sites is thinned to $34 \mathrm{~m}$ of extra ice-shelf thickness by the time it reaches AM01 (Equation (4)). The $396 \mathrm{~m}$ of meteoric ice that was present at AM04 will have thinned to $218 \mathrm{~m}$, giving an estimated total thickness of meteoric ice at AM01 of $252 \mathrm{~m}$. This agrees, within error margins, with the measured thickness of meteoric ice of $276 \mathrm{~m}$ (Table 2). Sensitivity tests show that a $1 \%$ change in strain rate produces $\sim 4 \mathrm{~m}$ calculated thickness change, whilst it would require a $10 \%$ change in snow density to produce the equivalent effect.

In making such estimates we should also consider thickness changes due to snow firnification (densification). Snow accumulating between any given pair of sites undergoes further firnification as it progresses downstream. This is not, however, a large contribution to thickness changes because of the layered structure of the shelf. The region $40 \mathrm{~km}$ upstream of and beyond point JP (Fig. 1) is an ablation and summer surface melt zone (Phillips, 1998), where the surface is comprised of dense continental glacier ice or superimposed ice. Thereafter local snowfall accumulates on the shelf. From fine-resolution stable-isotope analysis of the 2002/03 CHINARE core (personal communication from Li Yuansheng, 2006), the boundary between this locally accumulated snow layer and the solid ice is at a depth of $58.2 \mathrm{~m}$ at AM01. The transition depth can be calculated both upstream and downstream using snow accumulation data and thinning rates (Fig. 3). The depth is calculated as $17 \mathrm{~m}$ at JP, $44 \mathrm{~m}$ at AM04 and $58 \mathrm{~m}$ at 'Loose Tooth' (LT; Fig. 1). Compaction of quantities which are themselves only around $10 \%$ of the total shelf thickness produces corrections well within the error bounds of the overall calculations. Since we adopt strain values determined from surface speeds and flowband widths (Equation (3)), thickness change due to firnification has no impact on the calculation of the marine ice accretion rate and is ignored. Thickness changes can also occur due to compaction of the marine ice. We have no real information about this, but we can still make representative estimates of various quantities associated with marine ice formation.

We now apply Equation (4) to data along the flowband through AM01 and AM04 (Table 1) to estimate (1) mean annual marine ice accretion rates and (2) mean annual closure rates of the permeable marine ice between the two sites. With some additional assumptions (see section 4.4) we can also estimate these quantities upstream of AM04 and downstream of AM01 along the same flowband. We also estimate (3) the effective density of the total marine ice layer and (4) its average porosity. The results of these estimates are summarized in Table 2.

\subsection{Marine ice accretion rates along the AM01- AM04 flowband}

For $\dot{\varepsilon}_{z}=-0.0059 \mathrm{a}^{-1}$, the $207 \mathrm{~m}$ thick layer of marine ice at AM04 thinned to $113.9 \mathrm{~m}$ as it flowed to AM01. The measured thickness of marine ice at AM01 was $203 \mathrm{~m}$, indicating the addition of $89.1 \mathrm{~m}$ of new marine ice. This new marine ice (formed along the path from AM04 to AM01) also experienced thinning, so the actual accretion was greater than this. By inverting the contribution from the second term in Equation (4) we estimate an annual average accretion rate $\left(\dot{a}_{\mathrm{b}}\right)$ of $1.16 \mathrm{~m} \mathrm{a}^{-1}$ between AM04 and AM01, and a total accretion of new marine ice of $118.1 \mathrm{~m}$. This accretion rate was estimated from total marine ice thickness measurements and is therefore dependent on the average marine ice density between the two sites, which in this case is $935.5 \mathrm{~kg} \mathrm{~m}^{-3}$ (see section 4.5). Using a reference density of $920 \mathrm{~kg} \mathrm{~m}^{-3}$, the estimated density of impermeable marine ice (slightly higher than that for pure ice due to the presence of brine cells), the average accretion rate is $1.14 \mathrm{ma}^{-1}$. Accumulations of marine ice greater than $300 \mathrm{~m}$ thickness have been modelled at the base of the Filchner-Ronne Ice Shelf with accretion rates as low as $0.6 \mathrm{~m} \mathrm{a}^{-1}$ (Lange and MacAyeal, 1988).

Our estimate of the basal accretion rate is derived primarily from the change in marine ice thickness measured in the boreholes. It supports a mean value of $0.9 \mathrm{ma}^{-1}$ estimated from strain rates alone by Budd and others (1982) over the same interval upstream of G1. The maximum accretion rate determined from modelling ocean circulation in the AIS cavity by Williams and others (2002) exceeded 
Table 2. Measured, derived and assumed glaciological parameters along the JP-AM04-AM01-LT flowline. JP: Jetty Peninsula point; AM04: upstream drill site; AM01: downstream drill site; LT: Loose Tooth point. The distance, ice travel time, marine ice accretion rate and close-off rates are estimated between sites. The thicknesses of different ice layers, and at the two drill sites, densities, and the average porosity for the total marine ice layer, are also given

\begin{tabular}{|c|c|c|c|c|c|c|}
\hline \multirow[t]{2}{*}{ Site } & $\begin{array}{c}\text { Distance } \\
\text { (travel time) }\end{array}$ & $\begin{array}{l}\text { Ice thickness: } \\
\text { meteoric, total marine, } \\
\text { permeable marine }\end{array}$ & $\begin{array}{l}\text { Ice density: } \\
\text { meteoric, } \\
\text { total marine }\end{array}$ & $\begin{array}{l}\text { Accretion rate at } \\
920 \mathrm{~kg} \mathrm{~m}^{-3}\end{array}$ & $\begin{array}{l}\text { Close-off rate at } \\
920 \mathrm{~kg} \mathrm{~m}^{-3}\end{array}$ & $\begin{array}{l}\text { Average } \\
\text { porosity }\end{array}$ \\
\hline & km (years) & $\mathrm{m}$ & $\mathrm{kg} \mathrm{m}^{-3}$ & $\mathrm{ma}^{-1}$ & $\mathrm{ma}^{-1}$ & $\%$ \\
\hline$J P$ & & $690 \pm 20,0,0$ & & & & \\
\hline to & $88.1 \pm 1.5(223.7 \pm 6.0)$ & & & $1.3 \pm 0.2$ & $0.9 \pm 0.1$ & \\
\hline AM04 & & $396 \pm 2,207 \pm 2,71 \pm 2$ & $889 \pm 10,938 \pm 24$ & & & $19 \pm 22$ \\
\hline to & $67.8 \pm 1.0(101.5 \pm 3.0)$ & & & $1.1 \pm 0.2$ & $0.3 \pm 0.1$ & \\
\hline AM01 & & $276 \pm 2,203 \pm 2,103 \pm 2$ & $872 \pm 10,933 \pm 28$ & & & $14 \pm 17$ \\
\hline to & $62.7 \pm 1.0(63.4 \pm 2.0)$ & & & 0.0 (assumed) & 0.3 (assumed) & \\
\hline LT & & $170 \pm 12,103 \pm 8,37 \pm 11$ & & & & \\
\hline
\end{tabular}

$0.5 \mathrm{~m} \mathrm{a}^{-1}$, although that model assumed direct basal freezing. Earlier modelling by Williams and others (2001) indicated that the zone of modelled basal freezing approaching $1.0 \mathrm{~m} \mathrm{a}^{-1}$ located near Jetty Peninsula could lead to substantial marine ice accretion along an ice flowline through that region, although their analysis approximated both the velocities and thinning rates, and the predictions of marine ice thickness at G1 covered a wide range $(70 \mathrm{~m}$ to $>300 \mathrm{~m}$ ) for different choices of model ocean-circulation boundary conditions. For comparison, Bombosch and Jenkins (1995) modelled peak basal accretion rates of frazil ice at $>1.0 \mathrm{~m} \mathrm{a}^{-1}$ of solid ice.

An estimate of marine ice accretion upstream of AM04 is less accurate than between the boreholes, since it requires further assumptions. The distribution of Fricker and others (2001) indicates that marine ice accretion starts at point JP, adjacent to Jetty Peninsula and $88.1 \mathrm{~km}$ upstream of AM04 (Fig. 1). We calculated $\dot{\varepsilon}_{z}=-0.0035 \mathrm{a}^{-1}$ (via Equation (2)) and a travel time of 223.7 years over this distance. The $207 \mathrm{~m}$ of marine ice found at AM04 implied a total accretion along this path, after correction for en route thinning, of $297.2 \mathrm{~m}$. This is an average rate of $1.33 \mathrm{~m} \mathrm{a}^{-1}$ (Equation (4)) at an average density of $929 \mathrm{~kg} \mathrm{~m}^{-3}$ (section 4.5), or $1.32 \mathrm{~m} \mathrm{a}^{-1}$ at the reference density of marine ice $\left(920 \mathrm{~kg} \mathrm{~m}^{-3}\right)$.

Between AM01 and LT, closer to the AIS front (Fig. 1), the flow speed increases to $1150 \mathrm{~m} \mathrm{a}^{-1}$, flowband spreading increases down-shelf (Table 1) and $\dot{\varepsilon}_{z}=-0.0106 \mathrm{a}^{-1}$ (Equation (2)). An added complication toward the front of the ice shelf is the presence of longitudinal and transverse rifts that initiate formation of a $30 \mathrm{~km} \times 30 \mathrm{~km}$ iceberg known as the Loose Tooth (Fricker and others, 2002). We take LT as a point along the AM04-AM01 flowband immediately upstream of these rifts. This is $62.7 \mathrm{~km}$ and 63.4 years downstream from AM01. The mean annual accumulation rate over this section is $0.62 \mathrm{~m} \mathrm{a}^{-1}$ of snow, adding a strain-thinned total of $28.8 \mathrm{~m}$ of firn to the surface. Over this distance, the $276 \mathrm{~m}$ of meteoric ice from AM01 is thinned to $140.8 \mathrm{~m}$, so the total meteoric ice thickness expected at LT is $169.6 \mathrm{~m}$. The nearest RES measurements, $20 \mathrm{~km}$ south of LT, show a depth of around $170 \mathrm{~m}$ to the meteoric/marine ice interface.

A string of oceanographic salinity and temperature sensors deployed through the AM01 borehole has operated for 6 years. Comparison of these data with data from ocean moorings immediately off the ice front for the whole of 2001 indicates that there was no significant nett refreezing or melting between AM01 and the calving front (personal communication from $\mathrm{H}$. Leffanue, 2005). Results from the 1968 survey also showed that the nett basal melt-freeze downstream of G1 was close to zero (Budd and others, 1982). Since local melting probably takes place near the iceshelf front due to tidal pumping and seasonally warmer waters, it is possible that there is some basal freezing under part of the region between AM01 and LT in order for there to be no nett change overall. Adopting the assumption of no nett basal melt or freeze between AM01 and LT then, after the $203 \mathrm{~m}$ of marine ice present at AM01 has thinned to $103.5 \mathrm{~m}$, the total shelf thickness at LT is $273.1 \mathrm{~m}$ (Fig. 3). This is in reasonable agreement with ice radar measurements $20 \mathrm{~km}$ southeast of LT (east of the marine ice band) which yield a total thickness of $290 \mathrm{~m}$ in the area.

\subsection{Marine ice closure rates}

Below the hydraulic connection depth the marine ice is permeable. The permeability of this layer increases towards the base of the shelf. Above the hydraulic connection depth the brine channel networks are presumably sufficiently fine or so poorly interconnected that they can support the pressure load from the water column in the borehole. Eventually these close to form discrete cells which become smaller toward the meteoric/marine ice boundary. The extremely low salinities of the upper part of the impermeable marine ice remain somewhat enigmatic. Eicken and others (1994) showed that the normal desalination processes occurring in sea ice were inadequate to explain the extremely low salinities observed in marine ice from several Antarctic ice shelves. One major difference from the sea-ice case is that, as observed in the Amery boreholes, the situation can involve large platelets, initially in a relatively open, porous aggregation. A further complication is that the temperature profile through the shelf evolves as marine ice accumulates, and this may change the consolidation processes.

As well as new marine ice accumulating between AM04 and AM01, the upper part of the permeable layer (immediately below the hydraulic connection depth) slowly undergoes pore closure and becomes impermeable. The top of the permeable ice at AM04 was $137 \mathrm{~m}$ below the meteoric/marine ice interface. With strain thinning, this surface would be only $74.8 \mathrm{~m}$ below that interface at 


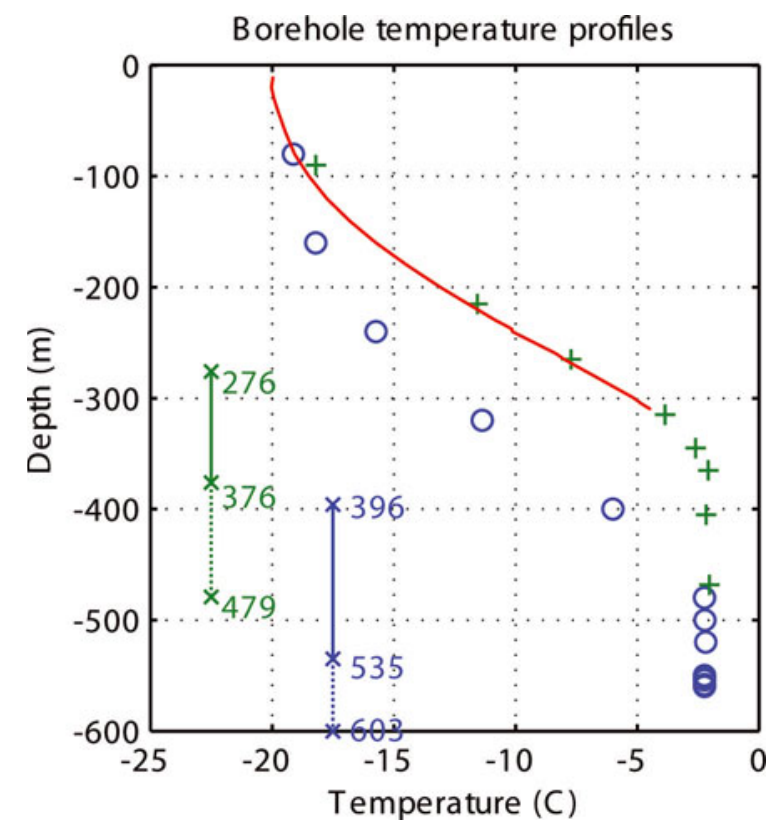

Fig. 5. Ice temperature profiles at the borehole sites AM01 (+) and AM04 (o). The deep marine ice has a near-isothermal profile at both sites (depth ranges marked as AM01 green (non-permeable: solid line; permeable: dotted line); AM04 blue (bottom left corner of plot)). Measurements from within the 1968 G1 borehole, geographically co-located with AM01, are shown for comparison (red curve). At AM04, temperatures were measured only 100 days after the borehole refroze. Temperature time series measured within the meteoric ice indicate that these measurements are within a few tenths of a degree of equilibration.

AM01. The measured depth of the hydraulic connection at AM01 was, however, $100 \mathrm{~m}$ below the meteoric/marine ice interface, indicating a downward migration of the pore close-off depth by $25.2 \mathrm{~m}$. This implies a closure of $33.4 \mathrm{~m}$ after strain correction (Equation (4)), requiring an average rate of closure in the permeable layer of $0.33 \mathrm{~m} \mathrm{a}^{-1}$, or $0.32 \mathrm{~m} \mathrm{a}^{-1}$ at the reference density $\left(920 \mathrm{~kg} \mathrm{~m}^{-3}\right)$. This is a little over a quarter of the average marine ice accretion rate between the sites.

The top $137 \mathrm{~m}$ impermeable layer of the total $207 \mathrm{~m}$ marine ice thickness at AM04 has become impermeable since accretion started at JP. Prior to strain thinning, closure would have occurred in a $195.2 \mathrm{~m}$ thick layer (Equation (4)), requiring an average upstream rate of closure of $0.87 \mathrm{~m} \mathrm{a}^{-1}$, or $0.86 \mathrm{ma}^{-1}$ at the reference density. This is about twothirds of the average accretion rate over the section. Initial closure rates can be expected to be higher until the permeable layer builds up sufficient thickness to create complex brine rejection pathways.

Strain thinning between AM01 and LT reduces the thickness of the permeable basal section from 103 to $52.5 \mathrm{~m}$. The average rate of closure of permeable marine ice was significantly lower between AM04 and AM01 than upstream of $\mathrm{AM04}$, and we would not expect it to increase downstream of AM01, particularly in the absence of significant additional marine ice accretion. Assuming the same closure rate over this section as between AM04 and AM01 $\left(0.32 \mathrm{~m} \mathrm{a}^{-1}\right)$, only another $15.3 \mathrm{~m}$ of marine ice (after strain correction) would be closed at LT and there would still be at least $37.3 \mathrm{~m}$ of permeable ice remaining at the base of the shelf. It is unlikely that this layer, isothermal
(Fig. 5) at the local freezing point, could survive contact with seasonally warm, near-surface waters tidally pumped under the ice shelf from Prydz Bay (Jacobs and others, 1992). Rapid loss of this basal permeable ice is likely to occur close to the front. Because hydrostatic equilibrium is averaged over a considerable area, a thinner shelf at the very front is not inconsistent with measured RES thicknesses (obtained a few kilometres upstream of the front during the 2002/03 field season) which vary between about 250 and $300 \mathrm{~m}$. Laser altimeter data from the Ice, Cloud and land Elevation Satellite (ICESat) also show a steep gradient right at the ice front in the marine ice zone, which can be attributed to melting of the permeable layer. There are regular sightings of green icebergs to the west of the AIS along the Mawson Coast. The green colour in these occurs in impermeable marine ice bands (Kipfstuhl and others, 1992; Warren and others, 1993). Many of these icebergs most likely originate from the AIS and are transported westward in the Antarctic Coastal Current. While the green colour indicates the presence of marine ice, no icebergs have been observed that have retained a layer of permeable ice after calving.

\subsection{Effective density of the marine ice layer}

The average density of the total ice-shelf column is given by

$$
\langle\rho\rangle=\rho_{\mathrm{w}} \frac{Z_{\mathrm{i}}-E}{Z_{\mathrm{i}}}
$$

where $Z_{\mathrm{i}}$ is the total ice thickness (meteoric plus marine), $E$ is the surface elevation and $\rho_{\mathrm{w}}$ is the (column-averaged) seawater density.

To obtain elevations relative to mean sea level, we converted GPS-derived surface elevations (referenced to the World Geodetic System 1984 (WGS84) ellipsoid) to elevations relative to the geoid using a recent (April 2008) Gravity Recovery and Climate Experiment (GRACE)-based static geoid model (EIGEN-GL04C; http://icgem.gfzpotsdam.de/ICGEM/ICGEM.htm) calculated for the WGS84 ellipsoid in the mean tide system (after King and others, 2005). Taking the average sea-water density for the upper $500 \mathrm{~m}$ of the water column determined from oceanographic measurements off the front of the ice shelf as $1028 \mathrm{~kg} \mathrm{~m}^{-3}$, the average density of the total ice column at AM04 is $906 \mathrm{~kg} \mathrm{~m}^{-3}$, and at AM01 it is $898 \mathrm{~kg} \mathrm{~m}^{-3}$. Density profiles were measured on the 1968 ice core recovered from G1 (the same location as AM01) (Budd and others, 1982) and on the 2003 CHINARE core drilled alongside AM01 (personal communication from Li Yuansheng, 2006). Combined, these measurements give an average density of the meteoric ice layer at AM01 of $872 \mathrm{~kg} \mathrm{~m}^{-3}$. Assuming the firn density profile in the locally precipitated meteoric ice at AM04 is the same as at AM01, we estimate the average density of the thicker meteoric ice layer at AM04 as $889 \mathrm{~kg} \mathrm{~m}^{-3}$. Considering the ice shelf as a two-layer structure, then the average density of the marine ice is $933 \mathrm{~kg} \mathrm{~m}^{-3}$ at AM01, and $938 \mathrm{~kg} \mathrm{~m}^{-3}$ at AM04. These values are higher than for pure ice $\left(917 \mathrm{~kg} \mathrm{~m}^{-3}\right)$, as they must be since the impermeable marine ice contains brine inclusions, while the deeper marine ice is permeated with sea water.

\subsection{Average porosity of the total marine ice layer}

We define porosity of the total marine ice layer, $\Phi_{\mathrm{mar}}$ as the ratio of the volume of sea water within the pores and cavities 
in the layer, to the total volume, such that

$$
\Phi_{\mathrm{mar}}=\frac{\rho_{\mathrm{mar}}-\rho_{\mathrm{i}}}{\rho_{\mathrm{w}}-\rho_{\mathrm{i}}},
$$

where $\rho$ is the density, and the subscripts mar, $\mathrm{i}$ and $\mathrm{w}$ refer to the average for the total marine ice layer, pure ice $\left(917 \mathrm{~kg} \mathrm{~m}^{-3}\right)$ and sea water $\left(1028 \mathrm{~kg} \mathrm{~m}^{-3}\right)$, respectively.

The average porosity for the marine ice layer at AM04 is $19 \pm 22 \%$, and at AM01 it is $14 \pm 17 \%$ (Table 2). The error in these estimates is large because of the relatively small difference between the density of the marine ice and that of pure ice (though clearly negative porosities are unrealistic). Borehole video observations qualitatively indicate that in the deepest and most permeable marine ice near the ice-shelf base, the cavities between the large platelets occupy $>50 \%$ of the total volume. An average porosity for the total marine ice layer of $14-20 \%$ is consistent with these observations. Above the hydraulic connection depth, the marine ice density will be only slightly greater than that of pure ice if the closed cells contain sea water, while between the hydraulic connection and the base of the shelf the effective density will gradually increase.

We have shown that earlier estimates of the marine ice thickness (Morgan, 1972; Fricker and others, 2001) are considerably lower than those measured in the two AIS boreholes. In part this arises because those estimates both used a low value for the density of marine ice. With no knowledge of the characteristics of the marine ice, Fricker and others (2001) assumed a density for the total marine ice layer equivalent to that of pure ice at $917 \mathrm{~kg} \mathrm{~m}^{-3}$. If the meteoric and marine ice average densities derived here were used, their estimated marine ice thicknesses at AM01 and at AM04 would increase to around 166 and $192 \mathrm{~m}$ respectively, values closer to the borehole measurements. Residual discrepancies are due to elevation differences at the sites (local GPS (this study); ERS-1 altimetry (Fricker and others, 2000, 2001)). Similar corrections to the marine ice thickness are required over the entire domain mapped by Fricker and others (2001), although the qualitative pattern of their derived thickness distribution remains valid.

\section{POTENTIAL IMPLICATIONS OF A PERMEABLE MARINE ICE LAYER}

\subsection{Location of marine ice bands relative to ice-shelf features}

The AIS-DEM of Fricker and others (2000) reveals long ridges and valleys from the southern grounding zone oriented along-flow which have also been detected by ICESat (Fricker and others, in press). Elevation profiles transverse to the ice flow show a ridge centred on the Fisher-Mellor suture which extends downstream to the AIS front where it terminates at the eastern rift of the Loose Tooth. In cross-sections upstream of the eastern marine ice band the surface elevations between this ridge and the western margin are consistently lower than the central flowbands of the AIS. This is most likely due to a combination of the influence of: (1) the Budd Ice Rumples $\left(71.50^{\circ} \mathrm{S}, 68.75^{\circ} \mathrm{E}\right)$; (2) generally thinner ice entering from the southern Prince Charles Mountains; and (3) the sheltering wall of the ice ridge on Jetty Peninsula. The shallower ice-shelf draft may make this region particularly well suited to the onset of frazil ice growth in a rising western boundary current and its subsequent deposition. The Budd Ice Rumples lie on the JP-AM04-AM01-LT flowline, $\sim 140 \mathrm{~km}$ upstream of $\mathrm{JP}$, and may be the source of the mineral debris recovered in the cores. While the thickest part of the eastern marine ice band originates along the western margin of the main AIS trunk, Fricker and others (2001) and Figure 1 also indicate appreciable marine ice at the confluence of the main trunk and the Scylla-Charybdis glacier flow entering from the west at the northern end of Jetty Peninsula. Indeed, the two marine ice bands flank this entering stream. The marine ice accretion might partly explain why the confluence at Jetty Peninsula does not display the complex, disrupted conditions observed at similar major junctions in Larsen B ice shelf (Glasser and Scambos, 2008). The Scylla-Charybdis flowband does show considerable disturbance (e.g. a crevasse train which propagates to the ice front) as it accelerates and turns to enter the main AIS, but the sutures to the adjoining ice appear more uniform than corresponding features on Larsen B.

\subsection{Influences of a marine ice layer on ice-shelf flow}

The bands where marine ice constitutes a major fraction of the ice-shelf thickness will influence ice-shelf flow, due to differences in ice material properties and temperature profiles (Lange and MacAyeal, 1986). Mechanically the deformation flow response of the marine ice to applied stresses will differ from that of meteoric ice (Hulbe and others, 2005), and is clearly likely to depend on brine inclusions and the level of ice porosity and consolidation. Ice deformation rates are also particularly sensitive to temperature (e.g. Budd and Jacka, 1989), and the marine ice accretion process has considerable influence on the temperature profile within the ice shelf. The borehole temperature profiles at AM04 and AM01 (Fig. 5) demonstrate this. In both locations, that portion of the marine ice layer below the close-off of the permeable marine ice is maintained at or near the in situ freezing point of sea water. The equilibrium temperature profile for regions with both surface and basal accretion of ice tends to display near-isothermal temperatures at top and bottom with a transition in between. Although basal conditions downstream of point JP have not been applied long enough to reach equilibrium, that general shape is observed. The temperature gradient in the ice shelf is also steepened by strain thinning. The essentially isothermal basal conditions produced by the presence of permeable marine ice mean there is no conductive heat flux through the ice shelf from the ocean cavity. Consequently, the vertical heat conduction above the isothermal zone (associated with the temperature gradient) simply cools the interior of the shelf. Towards the surface this heat conduction competes with the downward transport of colder meteoric ice from the surface. As the upper layers of impermeable marine ice cool, the remaining brine pockets must also become correspondingly more saline, and presumably the conduction also removes the associated heat of solidification

The AM04 temperature profile presented in Figure 5 was taken only 100 days after the borehole refroze, and temperatures may not have fully stabilized at pre-drilling conditions, but the ice near the meteoric/marine transition has cooled by approximately $1{ }^{\circ} \mathrm{C}$ between the two boreholes. The temperature gradients in this transition zone in the two borehole profiles correspond to heat fluxes of $130 \mathrm{~mW} \mathrm{~m}^{-2}$ at AM04 and $165 \mathrm{~mW} \mathrm{~m}^{-2}$ at AM01. A mean flux during transit between the boreholes of $147 \mathrm{~mW} \mathrm{~m}^{-2}$ constitutes a nett heat extraction over the 101.5 year period of $\sim 0.5 \mathrm{GJ} \mathrm{m}^{-2}$. This withdrawal of energy is sufficient to cool $100 \mathrm{~m}$ of ice by 
$2.5^{\circ} \mathrm{C}$ (or other thicknesses proportionately). It is not simple to apply this to the borehole records due to the strain thinning that also takes place, but such a heat flow at the meteoric/ marine interface appears more than sufficient to explain cooling in the upper portion of the marine ice band between the two boreholes. This heat extraction is equivalent to the latent heat of solidification of only $1.5 \mathrm{~m}$ of pure ice, and this thickness scales in proportion to the volume fraction of water in the upper layers of marine ice. Accordingly, heat conduction may play some role in the consolidation of the upper part of the marine ice, but from the high porosity of the overall marine ice column, the low salinity of the impermeable ice and the thickness of the isothermal zone, the bulk of the brine content is presumably expelled during consolidation, and most latent heat is apparently carried away by water circulation through the permeable layer.

Ice-shelf flow occurs predominantly in the horizontal plane, so the influence of the temperature profile in the marine ice region on flow is estimated by calculating the depth-averaged ice-flow viscosity coefficient, using the temperature dependence of ice deformation rates from Budd and Jacka (1989). The values calculated using the borehole temperatures were compared with those for temperature profiles computed for comparable conditions but without basal ice accretion. The results indicate a weakening of the viscosity flow parameter by approximately $15 \%$. Flow velocities across the front of the Filchner-Ronne Ice Shelf were best matched by models employing a temperature-based ice-softening parameter of around 10\% due to the presence of a basal marine ice layer (Lange and MacAyeal, 1986), while the observed flow pattern in the Stancomb-Wills ice tongue of the Brunt Ice Shelf is well reproduced only when marine ice in a narrow strip along its eastern front is weakened rather than thinned by the models (Hulbe and others, 2005). As we are considering the conventional Glen cubic flow relation (e.g. Budd and Jacka, 1989), this indicates that ice-shelf strain rates corresponding to similar (depth-averaged) stresses are increased by about $60 \%$ for the marine ice case. Thus, even setting aside the influence of salinity and the permeable ice zone on ice deformability, the marine ice bands will have a marked influence on ice flow. One consequence of higher depthaveraged average strain rates would be higher local stresses in the cold ice near the surface with the potential for greater surface crevassing. If the zones with thick marine ice prove more susceptible to thinning in regions of extending flow, they may thin faster than adjacent purely meteoric bands. If this geometry is favourable to further marine ice accretion, there may be a sustaining feedback.

\subsection{Increased vulnerability to ocean forcing}

Changes in thermal ocean forcing (i.e. increased ocean temperatures) can lead to ice-shelf thinning and retreat through enhanced basal melting (Rignot and Jacobs, 2002; Shepherd and others, 2003; Bentley and others, 2005). The AIS marine ice layer accounts for $>40 \%$ of the thickness of the ice shelf in some places, whilst the consequences of the permeability of the basal marine ice (which makes up roughly the lower half of the marine ice layer) are yet to be fully explored.

On the microscale, the high permeability of the very deep marine ice layer could enhance exchange of heat between the ocean and the deepest few tens of metres of the ice shelf. Heat exchange by convection within an open lattice system is faster than by conduction within solid ice. Higher up in the permeable marine ice, the scale of the drainage networks would decrease and restrict potential free movement of sea water. The lowest $100 \mathrm{~m}$ of the ice-shelf marine ice band is almost at the same temperature as the ocean (Fig. 5) and near the melting point, which has an additional though small impact on the ease of melt of the entire marine ice layer.

On the macroscale, the marine ice in the northwest part of the AIS is concentrated in bands. Even the loss of the deepest few tens of metres of highly permeable marine ice would substantially change the ice-thickness profiles across broad regions of the shelf, affecting both ice-shelf flow and sub-shelf ocean circulation. The redistribution of the basal pressure forcing, and of the driving stress in the shelf, which points down the thickness gradient, would directly influence ice flow. If the marine ice does not contribute greatly to the present ice-flow properties, the actual deformability of thinned regions may not be greatly changed, but these regions might be subjected to higher stresses if the overall flow changed. Would the former marine ice bands be compressed by thicker ice on either side flowing in, perhaps increasing transverse tensile stresses elsewhere? This could increase stresses at lines of potential weakness such as icestream suture zones. Recall that the Fisher-Mellor suture appears to coincide with the eastern Loose Tooth rift. The loss of marine ice near Jetty Peninsula and at the beginning of the western marine ice band might also alter the bonding of the various flowbands. Sanderson (1979) explored iceshelf flow in diverging bays, and suggested that the AIS is already near the limit for retaining contact with the sides of its embayment. Sanderson's analysis suggests that substantial thinning of the AIS might lead to earlier detachment, which would likely lead to accelerated flow. These are important questions for modellers to address, as the partial rupturing of sutures between flow units, via a dynamic lateral flow response to a rapid loss of buoyancy, has been identified as one of several preconditions for ice-shelf collapse (Glasser and Scambos, 2008).

Finally, as an interesting aside, the protected habitat and greater surface area of the permeable marine ice also has as yet unexplored implications for sub-ice-shelf ecosystems (Riddle and others, 2007; Roberts and others, 2007).

\section{CONCLUSION}

We have examined a band of deep marine ice under the northwestern region of the AIS using hot-water drilling and coring techniques, and a borehole probe ice video system. Boreholes were drilled at two sites on approximately the same flowline ( $\sim 70 \mathrm{~km}$ apart) where marine ice thicknesses were greater than $200 \mathrm{~m}$. It was found that, while the top of the marine ice layer was mostly impermeable with small brine inclusions, the bottom 70-100 m of the layer consisted of ice platelets fused together to form a permeable matrix filled with sea water.

Analysis of the data shows:

1. an average accretion rate of marine ice of $1.1 \pm 0.2 \mathrm{~m} \mathrm{a}^{-1}$ between 170 and $100 \mathrm{~km}$ from the calving front, and a higher average rate further upstream of $1.3 \pm 0.2 \mathrm{~m} \mathrm{a}^{-1}$;

2. an average rate of closure of the uppermost permeable marine ice of $0.3 \pm 0.1 \mathrm{~m} \mathrm{a}^{-1}$ between borehole sites, with a higher value of $0.9 \pm 0.1 \mathrm{~m} \mathrm{a}^{-1}$ upstream; 
3. an average density of the total marine ice layer of $933 \pm 18 \mathrm{~kg} \mathrm{~m}^{-3}$ at AM01 and $938 \pm 24 \mathrm{~kg} \mathrm{~m}^{-3}$ at AM04;

4. an estimated average porosity of the total marine ice layer of $14-20 \%$ (implying much higher values in the deep basal ice).

With its own set of unique thermal and mechanical properties, the presence of marine ice has important ramifications for the dynamical modelling of ice-shelf processes and interaction with sea water in the ocean cavities beneath them. Recognition of the denser character of marine ice should prompt a re-evaluation of estimates of ice-shelf draft and may be significant for sub-ice ocean circulation studies. Furthermore, since the very deepest marine ice is highly permeable it may be more vulnerable to melt by intrusions of warmer sea water, and/or more vigorous circulation in the ice-shelf cavity. Partial loss of these substantial marine ice layers could have a significant influence on ice-shelf flow and sub-ice ocean circulation. It might also alter the bonding between separate flow units within the ice shelf. Such considerations are applicable to other Antarctic ice shelves with substantial marine ice layers at their bases.

\section{ACKNOWLEDGEMENTS}

We acknowledge logistic support from the Australian Antarctic Division (AAD) and valuable contributions from many people who contributed to the Amery Ice Shelf Ocean Research (AMISOR) field program. We thank N. Young and J. Bassis, who provided valuable discussions and contributions to this work. This work was supported by the Australian Government's Cooperative Research Centres Program through the Antarctic Climate and Ecosystems Cooperative Research Centre (ACE CRC). The Antarctic Ice Borehole Probe (video camera system) was developed at the Jet Propulsion Laboratory, California Institute of Technology (CalTech), under a contract with NASA. We thank NASA Headquarters, NASA's Office of Earth Science, the US National Science Foundation Office of Polar Programs, and CalTech's Geological and Planetary Sciences Division for support, and we are grateful to the Polar Research Institute of China for access to their ice-core data. We acknowledge the contribution of two anonymous referees whose reviews substantially improved the manuscript.

\section{REFERENCES}

Bentley, M.J. and 6 others. 2005. Early Holocene retreat of the George VI Ice Shelf, Antarctic Peninsula. Geology, 33(3), 173-176.

Bombosch, A. and A. Jenkins. 1995. Modeling the formation and deposition of frazil ice beneath Filchner-Ronne Ice Shelf. J. Geophys. Res., 100(C4), 6983-6992.

Budd, W.F. and T.H. Jacka. 1989. A review of ice rheology for ice sheet modelling. Cold Reg. Sci. Technol., 16(2), 107-144.

Budd, W.F., M.J. Corry and T.H. Jacka. 1982. Results from the Amery Ice Shelf Project. Ann. Glaciol., 3, 36-41.

Carsey, F., A. Behar, A.L. Lane, V. Realmuto and H. Engelhardt. 2002. A borehole camera system for imaging the deep interior of ice sheets. J. Glaciol., 48(163), 622-628.

Corry, M.J. 1987. The Amery Ice Shelf saga part 3: 1969-70. Aurora, 6(3), 25-29.

Craven, M. and 6 others. 2004. Initial borehole results from the Amery Ice Shelf hot-water drilling project. Ann. Glaciol., 39, 531-539.
Craven, M. and 7 others. 2005. Borehole imagery of meteoric and marine ice layers in the Amery Ice Shelf, East Antarctica. J. Glaciol., 51(172), 75-84.

Eicken, H., H. Oerter, H. Miller, W. Graf and J. Kipfstuhl. 1994. Textural characteristics and impurity content of meteoric and marine ice in the Ronne Ice Shelf, Antarctica. J. Glaciol., 40(135), 386-398.

Engelhardt, H. and J. Determann. 1987. Borehole evidence for a thick layer of basal ice in the central Ronne Ice Shelf. Nature, 327(6120), 318-319.

Engelhardt, H., B. Kamb and R. Bolsey. 2000. A hot-water ice-coring drill. J. Glaciol., 46(153), 341-345.

Fricker, H.A., G. Hyland, R. Coleman and N.W. Young. 2000. Digital elevation models for the Lambert Glacier-Amery Ice Shelf system, East Antarctica, from ERS-1 satellite radar altimetry. J. Glaciol., 46(155), 553-560.

Fricker, H.A., S. Popov, I. Allison and N. Young. 2001. Distribution of marine ice under the Amery Ice Shelf, East Antarctica. Geophys. Res. Lett., 28(11), 2241-2244.

Fricker, H.A., N.W. Young, I. Allison and R. Coleman. 2002. Iceberg calving from the Amery Ice Shelf, East Antarctica. Ann. Glaciol., 34, 241-246.

Fricker, H.A., R. Coleman, L. Padman, T.A. Scambos, J. Bohlander and K.M. Brunt. In press. Mapping the grounding zone of the Amery Ice Shelf, East Antarctica using InSAR, MODIS and ICESat. Antarct. Sci.

Glasser, N.F. and T.A. Scambos. 2008. A structural glaciological analysis of the 2002 Larsen B ice-shelf collapse. J. Glaciol., 54(184), 3-16.

Grosfeld, K., R. Gerdes and J. Determann. 1997. Thermohaline circulation and interaction between ice shelf cavities and the adjacent open ocean. J. Geophys. Res., 102(C7), 15,595-15,610.

Hulbe, C.L., R. Johnston, I. Joughin and T. Scambos. 2005. Marine ice modification of fringing ice shelf flow. Arct. Antarct. Alp. Res., 37(3), 323-330.

Jacobs, S.S., H.H. Hellmer, C.S.M. Doake, A. Jenkins and R.M. Frolich. 1992. Melting of ice shelves and the mass balance of Antarctica. J. Glaciol., 38(130), 375-387.

King, M.A., N.T. Penna, P.J. Clarke and E.D. King. 2005. Validation of ocean tide models around Antarctica using onshore GPS and gravity data. J. Geophys. Res., 110(B8), B08401. (10.1029/ 2004JB003390.)

Kipfstuhl, J., G.S. Dieckmann, H. Oerter, H. Hellmer and W. Graf. 1992. The origin of green icebergs in Antarctica. J. Geophys. Res., 97(C12), 20,319-20,324.

Lambrecht, A., H. Sandhager, D.G. Vaughan and C. Mayer. 2007. New ice thickness maps of Filchner-Ronne Ice Shelf, Antarctica, with specific focus on grounding lines and marine ice. Antarct. Sci., 19(4), 521-532.

Lange, M.A. and D.R. MacAyeal. 1986. Numerical models of the Filchner-Ronne Ice Shelf: an assessment of reinterpreted ice thickness distributions. J. Geophys. Res., 91(B10), $10,457-10,462$

Lange, M.A. and D.R. MacAyeal. 1988. Numerical models of steadystate thickness and basal ice configurations of the central Ronne Ice Shelf, Antarctica. Ann. Glaciol., 11, 64-70.

Leffanue, H. and M. Craven. 2004. Circulation and water masses from current meter and T/S measurements at the Amery Ice Shelf. FRISP Rep. 15, 73-79.

Lewis, E.L. and R.G. Perkin. 1986. Ice pumps and their rates. J. Geophys. Res., 91(C10), 11,756-11,762.

Makinson, K. 1993. The BAS hot water drill: development and current design. Cold Reg. Sci. Technol., 22(1), 121-132.

Millero, F.J. 1978. Annex 6. Freezing point of sea water. In Eighth Report of the Joint Panel on Oceanographic Tables and Standards. Paris, UNESCO, 29-35. (Technical Papers in Marine Science 28.)

Moore, J.C., A.P. Reid and J. Kipfstuhl. 1994. Microstructure and electrical properties of marine ice and its relationship to meteoric ice and sea ice. J. Geophys. Res., 99(C3), $5171-5180$. 
Morgan, V.I. 1972. Oxygen isotope evidence for bottom freezing on the Amery Ice Shelf. Nature, 238(5364), 393-394.

Neal, C.S. 1979. The dynamics of the Ross Ice Shelf revealed by radio echo-sounding. J. Glaciol., 24(90), 295-307.

Oerter, H. and 6 others. 1992. Evidence for basal marine ice in the Filchner-Ronne Ice Shelf. Nature, 358(6385), 399-401.

Phillips, H.A. 1998. Surface meltstreams on the Amery Ice Shelf, East Antarctica. Ann. Glaciol., 27, 177-181.

Riddle, M.J., M. Craven, P.M. Goldsworthy and F. Carsey. 2007. A diverse benthic assemblage $100 \mathrm{~km}$ from open water under the Amery Ice Shelf, Antarctica. Paleoceanography, 22(P12), P1204. (10.1029/2006PA001327.)

Rignot, E. and S.S. Jacobs. 2002. Rapid bottom melting widespread near Antarctic ice sheet grounding lines. Science, 296(5575), 2020-2023.

Roberts, D., M. Craven, M.-H. Cai, I. Allison and G. Nash. 2007. Protists in the marine ice of the Amery Ice Shelf, East Antarctica. Polar Biol., 30(2), 143-153.

Sanderson, T.J.O. 1979. Equilibrium profile of ice shelves. J. Glaciol., 22(88), 435-460.

Sanderson, T.J.O. and C.S.M. Doake. 1979. Is vertical shear in an ice shelf negligible? J. Glaciol., 22(87), 285-292.

Scambos, T.A., T.M. Haran, M.A. Fahnestock, T.H. Painter and J. Bohlander. 2007. MODIS-based Mosaic of Antarctica (MOA) data sets: continent-wide surface morphology and snow grain size. Remote Sens. Environ., 111(2-3), 242-257.

Shepherd, A., D. Wingham, T. Payne and P. Skvarca. 2003. Larsen ice shelf has progressively thinned. Science, 302(5646), 856-859.
Thyssen, F. 1988. Special aspects of the central part of FilchnerRonne Ice Shelf, Antarctica. Ann. Glaciol., 11, 173-179.

Thyssen, F., A. Bombosch and H. Sandhðger. 1993. Elevation, ice thickness and structure mark maps of the central part of the Filchner-Ronne Ice Shelf. Polarforschung, 62(1), 17-26.

Tison, J.L., A. Khazendar and E. Roulin. 2001. A two-phase approach to the simulation of the combined isotope/salinity signal of marine ice. J. Geophys. Res., 106(C12), 31,387-31,401.

Warren, S.G., C.S. Roesler, V.I. Morgan, R.E. Brandt, I.D. Goodwin and I. Allison. 1993. Green icebergs formed by freezing of organic-rich seawater to the base of Antarctic ice shelves. J. Geophys. Res., 98(C4), 6921-6928.

Wen, J., K.C. Jezek, B. Csatho, U.C. Herzfeld, K.L. Farness and P. Huybrechts. 2007. Mass budgets of the Lambert, Mellor and Fisher Glaciers and basal fluxes beneath their flowbands on Amery Ice Shelf. Sci. China D, 50(11), 1693-1706.

Wen, J. and 7 others. 2008. Mass budget of the grounded ice in the Lambert Glacier-Amery Ice Shelf system. Ann. Glaciol., 48, 193-197.

Williams, M.J.M., K. Grosfeld, R.C. Warner, R. Gerdes and J. Determann. 2001. Ocean circulation and ice-ocean interaction beneath the Amery Ice Shelf, Antarctica. J. Geophys. Res., 106(C10), 22,383-22,399.

Williams, M.J.M., R.C. Warner and W.F. Budd. 2002. Sensitivity of the Amery Ice Shelf, Antarctica, to changes in the climate of the Southern Ocean. J. Climate, 15(19), 2740-2757.

Young, N.W. and G. Hyland. 2002. Velocity and strain rates derived from InSAR analysis over the Amery Ice Shelf, East Antarctica. Ann. Glaciol., 34, 228-234.

MS received 22 August 2008 and accepted in revised form 30 April 2009 